\title{
Test of Policy Ineffectiveness Proposition with Real Expectations for Turkey
}

\author{
Serdar Kurt ${ }^{1}$ \\ ${ }^{1}$ Department of Econometrics, Canakkale Onsekiz Mart University, Canakkale, Turkey \\ Correspondence: Serdar Kurt, Department of Econometrics, Faculty of Economics and Administrative Science at \\ Biga, Canakkale Onsekiz Mart University, 17200, Biga, Canakkale, Turkey. Tel: 90-286-335-8738-1190. E-mail: \\ serdarkurt10@gmail.com
}

Received: February 26, 2015

Accepted: March 16, 2015

Online Published: March 25, 2015

doi:10.5539/ijef.v7n4p199

URL: http://dx.doi.org/10.5539/ijef.v7n4p199

\begin{abstract}
The purpose of this study is to determine the validity of Policy Ineffectiveness Proposition (PIP) for the study period in which Inflation Targeting policy is kept transparent and accountability at the forefront. In the study, seasonally adjusted and seasonally unadjusted data was analyzed with Cobb-Douglas Production Function (CDPF), Lucas Aggregate Supply Function (LASF), Variance Autoregressive (VAR) and Impulse-Response Functions. Expectations series are calculated using the real expectations data obtained from the surveys conducted across the public and private sectors by the central banks.

The simultaneous effects of anticipated and unanticipated expectations of inflation and exchange rate on real output are tested using CDPF and LASF. In general, the results obtained from CDPF and LASF do not support the PIP. Looking at the results of VAR analysis, it has been determined that coefficients of anticipated expectations and some unanticipated expectations are significant. The results of Impulse-Response analysis have shown that any innovation or shock in unanticipated expectations leads to an increase in anticipated expectations of inflation. In addition, in the case of a new innovation or shock in the set of information available about the anticipated expectations, it can be said that it takes between five and eight months for the real sector to incorporate this update. The results of VAR and Impulse-Response analysis also do not support the PIP.
\end{abstract}

Keywords: policy ineffectiveness proposition, anticipated and unanticipated expectations, VAR analysis, rational expectations

\section{Introduction}

Expectations were first thought to be rational by Muth (1961), who defined the Rational Expectations Hypothesis more precisely as follows.

...that expectations of firms (or, more generally, the subjective probability distribution of outcomes) tend to be distributed, for the same information set, about the prediction of the theory (or the "objective" probability distributions of outcomes) (Muth, 1961, p. 316).

According to the rational expectations hypothesis; while forming their expectations of the future, economic agents fully use all the existing -albeit scarce - information. Since it is assumed that economic agents do not make systematic errors, expected values of prediction errors are zero and do not contain autocorrelation.

Lucas (1973) and Sargent and Wallace (1975) developed PIP based on the idea that only the unanticipated policies are effective on real variables; however anticipated policies have no effect on these variables. Barro $(1977,1978)$ who was first to analyse PIP empirically, tested relations of anticipated and unanticipated monetary policies with unemployment and real output for the US. The results of both of Barro's studies (1977, 1978) determined that only unanticipated monetary policies were effective on real output and unemployment. Results supporting PIP were achieved by Batchelor and Sherif (1980) with seasonally adjusted data for England, by Wogin (1980) for Canada, by Canarella \& Pollard (1989) for 16 Latin American countries, by Khan (2008) with data that take seasonality into account for Pakistan, and by Komijani et al. (2012) for Iran.

Criticising the method of Barro (1977, 1978), Mishkin (1982) used nonlinear generalized least squares method in estimation of his equations. The results of Mishkin's (1982) study using seasonally adjusted data for the US, Darrat's (1985) study on Italy, Mohabbat \& Al-Saji's (1991) study on Iraq, Cover's (1992) study using 
seasonally adjusted data for the US, Marashdeh's (1993) study on Malaysia, Karras's (1996) study on 38 countries, Chu and Ratti's (1997) study on Japan, Begum's (1997) study on Bangladesh, and Karras and Stokes' (1999) study using seasonally adjusted data for the US do not support PIP. The results of the study carried out by Hucket (2003) using seasonally adjusted data for Economic Monetary Union supported PIP for some of the countries while not supporting others.

Uygur (1983) is prominent in the studies dealing with the Turkish Economy. His study of the validity of the PIP in the manufacturing industry was investigated with Lucas' (1973) supply function using quarterly series on the real expectations calculated through survey data and PIP was rejected. Results not supporting PIP were obtained by Yamak and Kucukkale's (1998) study using quarterly data, McGee and Stasiak's (1985) study using VAR model, Peker's (2007) study, and Cochrane's (1998) model based on VAR using seasonally adjusted monthly data. On the other hand, Abaan (1987) using quarterly data, and Tanriover and Yamak (2012) using seasonally adjusted quarterly data obtained results supporting PIP. Bilgili (1999) accepted PIP for quarterly US data but rejects it for Turkey. In Taban's (2004), study PIP is supported when narrow money supply (M1) is used; however it does not support it when a broader money supply (M2) is used. Hasanov (2006) concluded that for the quarterly data, PIP is supported when the distinction between unanticipated expansionary and contractionary monetary policy is rejected, but it isn't supported when the distinction is recognised. Berument and Ceylan (2010) investigated the effects of anticipated and unanticipated United States Federal Funds target rate changes on the domestic interest rates of developed and developing/emerging countries for the period of 1989-2008. Results provided supporting PIP and suggested unanticipated changes have a greater effect than anticipated changes and the significant effects are greater in the developed markets than developing/emerging markets. Berument, et al. (2007) reached the similar results for the Turkish economy. Sulku (2011) tested the long run neutrality of money for the Turkish economy and monetary aggregates M1, M2, M2Y and M3 applying Fisher and Seater (1993) ARIMA framework during the period of 1987:01-2006:03. The results hold long run neutrality of money hypothesis under all alternative monetary aggregates and PIP cannot be rejected. Altunoz (2014) rejected neutrality of Money hypothesis that suggested by quantity theory of money for 1985-2013 by using unit root, cointegration and Granger causality tests and nevertheless PIP is rejected. Tuğcu (2015) Hatemi-J (2008) tested Neutrality of Money Hypothesis in Turkey for the period 1960-2012 using cointegration test and concluded that Neutrality Hypothesis does not hold for Turkey so that PIP hypothesis is rejected.

Based on the above, it is clear that consensus has not been achieved on the effectiveness of anticipated and unanticipated expectations and the validity of PIP. While the results of some studies support PIP, others do not and in this regard the topic is still debated. In addition, the PIP test is usually done by derivation of anticipated and unanticipated expectations through econometric models, although the number of the studies using real data and surveys are very limited. In this study, adopting a different approach, the anticipated expectations are defined as modified means of the questionnaires distributed by The Central Bank of the Republic of Turkey (CBRT). They are not derived using any model or equation. Both seasonally adjusted and unadjusted data are included in the analysis. Thus, the effect of seasonal adjustments on the results could be observed. In the study period, inflation targeting monetary policy that the CBRT uses to constantly inform the public, that requires high levels of independence, transparency and accountability from the CBRT, is implemented. For this reason, the expectations during this period are predicted to be more anticipated and rational. Also during this period, inflation is lower and more stable compared to previous periods.

In the first part of the study, the literature associated with the PIP takes part, the second part includes the examination of the development and change of rationality in the process of inflation targeting in Turkey. In the third part of the study data and to apply econometric methods have been introduced and the results obtained from this study are presented in tables. The results obtained from the study have been interpreted and proposals are offered in the conclusion section.

The aim of the study is to determine the impact of anticipated and unanticipated expectations on real output using monthly data from 2006:01-2012:12 in which Inflation Targeting policy is kept transparent and accountability at the forefront. The results obtained from CDPF, LASF, VAR and impulse-response analysis do not support the PIP.

\section{Inflation Targeting and Rationality}

The inflation-targeting monetary policy was implemented in the 2002-2014 period in Turkey, and is still being continued. One of the most important features of the inflation-targeting program is that the CBRT is independent, transparent, and accountable. A law (Note 1) issued in 2001 ensured that the CBRT was to have instrument independence; and its transparency and accountability was increased. 4th article of this law emphasizes that the 
main objective of the Central Bank is to maintain price stability and it can directly determine the monetary policy and monetary policy tools it will use to achieve this objective. Central Bank is has been described as the only competent and responsible authority to determine the monetary policy instruments and implement monetary policy. However, it can support the economic growth and employment policies of the government provided that they do not conflict with price stability goal.

The CBRT - which is independent, transparent and accountable - declares the target rate of inflation to the public beforehand and which policies it will implement to meet the target. The CBRT is primarily responsible for the achievement of the target; and if the target is not met the reasons for this should be explained to the public. Credibility and sustainability of inflation-targeting policy of CBRT is adversely affected if the target is not met.

Although Bade and Parkin (1978) determined that the independence of the central bank has limited impact on inflation, the study, Bernanke et al. (1999) carried out on 7 countries shows that the increase in independence of the central bank reduces both the inflation rate and public inflation expectations. Klomp and de Haan (2010) have used the results of previously conducted 59 studies and determined that the results vary according to independence indicator, country, period, and model specification and estimation methoids however the variety isn't derived from independence indicator. The results of meta-analysis carried out using the conclusion of 59 empirical studies presents that independence of central bank have a really significant negative impact on inflation.

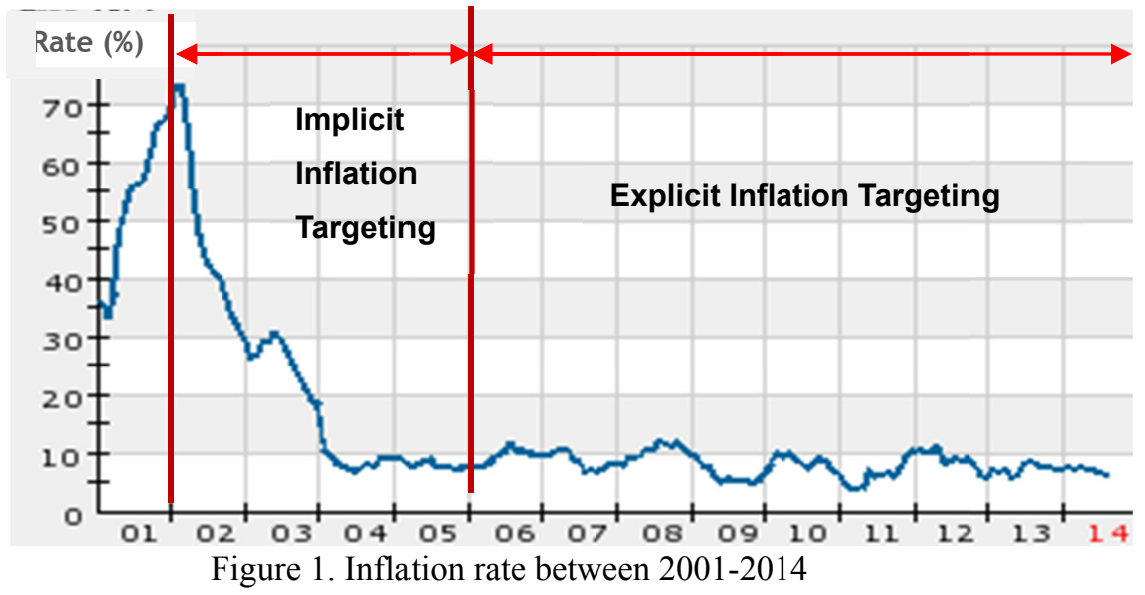

Note. http://www.tcmb.gov.tr/. Accessed: 28.08.2014.

The inflation-targeting which was implemented implicitly between 2002 and 2005, shifted to explicit from 2006 onwards in Turkey. In case of implicit inflation targeting the central bank targets the inflation implicitly and use all its opportunities to achieve this goal. As seen in Fig 1 as a result of increase in independency, transparency and accountability of the central bank, implementation of implicit inflation targeting program has been successful and inflation has decreased to $8-9 \%$ from $70-80 \%$. The inflation rate seared in this level of inflation and it became hard to reduce inflation below these levels. Explicit inflation targeting policy was adopted enable further reduce in inflation.

In the case of the CBRT being transparent and accountable, inflation rate targets being declared beforehand, clarification on which policies will be implemented to meet the target, and - if the target is not met, -what steps will be taken, it is believed that expectations will be more rational because the CBRT informs and updates the public consistently. Moreover, after 2006 the inflation rate volatility fell and subsequently stabilized; hence became easier and more accurate to estimate the more stable inflation rate. For this reasons, expectations are expected to be more rational and support PIP in the period after 2006.

\section{Econometric Analysis and Data}

The effects of the real anticipated and unanticipated survey expectations series on real variables are analysed with monthly data for the period of 2006:01-2012:12 when inflation targeting was implemented in the Turkish economy. Both seasonally adjusted and unadjusted series are used in the analysis. All the variables used in the analysis were collected from the CBRT Electronic Data Delivery System. Modified mean (Note 2) values obtained from surveys conducted by the CBRT were used as anticipated series of expectations. Anticipated 
monthly $\left(p_{m}^{a}\right)$, annual (twelve months, $\left.p_{y}^{a}\right)$, and year-end $\left(p_{y e}^{a}\right)$ inflation expectation of CPI (Consumer Price Index), and anticipated monthly $\left(e r_{m}^{a}\right)$ and year-end $\left(e r_{y e}^{a}\right)$ expectation of exchange rate of US Dollar are included in the data.

Unanticipated inflation values were obtained by subtracting anticipated rate of inflation from the inflation rate $(p)$ calculated using CPI $(2003=100)$ index of realisation values, and unanticipated exchange rate were obtained by subtracting anticipated exchange rate from the exchange rate $(\mathrm{er})$ of US Dollar .

Accordingly, monthly $\left(p_{m}^{u a}=p_{m}-p_{m}^{a}\right)$, annual (twelve months) $\left(p_{y}^{u a}=p_{y}-p_{y}^{a}\right)$ and year-end $\left(p_{y e}^{u a}=p_{y e}-\right.$ $\left.p_{y e}^{a}\right)$ values of unanticipated inflation expectations, and monthly $\left(e r_{y e}^{u a}=e r_{y e}-e r_{y e}^{a}\right)$, year-end $\left(e r_{y e}^{u a}=e r_{y e}-\right.$ $e r_{y e}^{a}$ ) values of unanticipated exchange rate expectation are calculated.

In the economic growth equation, growth rate of industrial production index $(2010=100)$ as real output $(y)$, growth rate of intermediate goods (Note 3) production index as the capital $(k)$, and growth rate of labour force as labour $(l)$ data are used. To take the effects of the Global Financial Crisis into account, the Crisis variable $D_{c}$ is formed by specifying the period 2008:12-2009:03 when the effects of the crisis were the most intense as 1 and the other periods as 0 .

\subsection{Augmented Dickey-Fuller (ADF) Test}

In this study, whether variables are stationary or not is significant in two respects. First, the variables used in the time series analysis should be stationary and should not contain unit root to prevent spurious regressions. In the event of lack of stationary of variables and spurious regression estimates, the estimations and the equation results won't be reliable. Secondly, non-stationary series show Random Walk property. Determining the future values of such series or estimating is difficult. Stationary series are predictable because they disperse around a certain mean with fixed variance. Stationary of series means series can be estimated easily by individuals with rational expectations. One of the most basic and widely used tests to investigate whether or not the variables are stationary is the ADF test.

The ADF test was developed by Dickey and Fuller (1979, 1981). For a variable Y, stationarity of which is investigated in the ADF test, none, intercept and intercept and trend models are as follows:

$$
\begin{gathered}
\Delta Y_{t}=\rho Y_{t-1}+\sum_{i=1}^{p} \alpha_{i} \Delta Y_{t-i}+e_{t} \text { (None) } \\
\Delta Y_{t}=\alpha_{0}+\rho Y_{t-1}+\sum_{i=1}^{p} \alpha_{i} \Delta Y_{t-i}+e_{t} \text { (Intercept) } \\
\Delta Y_{t}=\alpha_{0}+T+\rho Y_{t-1}+\sum_{i=1}^{p} \alpha_{i} \Delta Y_{t-i}+e_{t} \text { (Intercept and Trend) }
\end{gathered}
$$

An optimal lag length of the dependent variable is located on the right side of the equations as an explanatory variable in order to eliminate autocorrelation. Modified Akaike Information Criterion is used to determine the optimal lag length in the equation. If $\mathrm{t}$ statistics calculated for coefficient of $e_{t}$ is greater than the MacKinnon (1996) table value, the null hypothesis, which expresses that the series is non-stationary, is rejected, so the series is stationary. Otherwise, the null hypothesis cannot be rejected and it is determined that the series is non-stationary.

Table 1. ADF test (seasonally unadjusted)

\begin{tabular}{clll}
\hline Variables & None & Intercept & Intercept and Trend \\
\hline $\boldsymbol{y}$ & $-13.32(0)^{\mathrm{a}}$ & $-13.32(0)^{\mathrm{a}}$ & $-13.25(0)^{\mathrm{a}}$ \\
$\boldsymbol{k}$ & $-5.27(2)^{\mathrm{a}}$ & $-5.24(2)^{\mathrm{a}}$ & $-5.20(2)^{\mathrm{a}}$ \\
$\boldsymbol{l}$ & $-0.74(11)$ & $-3.43(0)^{\mathrm{a}}$ & $-3.44(0)^{\mathrm{c}}$ \\
$\boldsymbol{p}_{\boldsymbol{m}}^{\boldsymbol{a}}$ & $-0.25(11)$ & $-5.32(0)^{\mathrm{a}}$ & $-5.30(0)^{\mathrm{a}}$ \\
$\boldsymbol{p}_{\boldsymbol{m}}^{\boldsymbol{u} \boldsymbol{a}}$ & $-8.77(0)^{\mathrm{a}}$ & $-8.72(0)^{\mathrm{a}}$ & $-8.68(0)^{\mathrm{a}}$ \\
$\boldsymbol{p}_{\boldsymbol{y}}^{\boldsymbol{a}}$ & $-0.24(1)$ & $-3.78(1)^{\mathrm{a}}$ & $-3.70(1)^{\mathrm{b}}$ \\
$\boldsymbol{p}_{\boldsymbol{y}}^{\boldsymbol{u} \boldsymbol{a}}$ & $-1.98(0)^{\mathrm{b}}$ & $-2.41(0)$ & $-2.69(0)$ \\
$\boldsymbol{p}_{\boldsymbol{y} \boldsymbol{e}}^{\boldsymbol{a}}$ & $-0.41(0)$ & $-2.86(0)^{\mathrm{b}}$ & $-3.02(0)$ \\
$\boldsymbol{p}_{\boldsymbol{y} \boldsymbol{e}}^{\boldsymbol{u}}$ & $-2.85(0)^{\mathrm{a}}$ & $-2.81(0)^{\mathrm{c}}$ & $-2.74(0)$ \\
$\boldsymbol{e} \boldsymbol{r}_{\boldsymbol{m}}^{\boldsymbol{a}}$ & $-2.25(1)^{\mathrm{b}}$ & $-2.33(1)$ & $-2.39(1)$ \\
$\boldsymbol{e r}_{\boldsymbol{m}}^{\boldsymbol{u a}}$ & $-7.91(0)^{\mathrm{a}}$ & $-7.99(0)^{\mathrm{a}}$ & $-7.97(0)^{\mathrm{a}}$ \\
$\boldsymbol{e} \boldsymbol{r}_{\boldsymbol{y} \boldsymbol{a}}^{\boldsymbol{a}}$ & $-2.10(2)^{\mathrm{b}}$ & $-2.12(2)$ & $-2.26(2)$ \\
$\boldsymbol{e r}_{\boldsymbol{y} \boldsymbol{e}}^{\boldsymbol{a}}$ & $-7.35(0)^{\mathrm{a}}$ & $-7.40(0)^{\mathrm{a}}$ & $\left.-7.34)^{\mathrm{a}} 0\right)^{\mathrm{a}}$ \\
\hline
\end{tabular}

Note. a, b, c respectively significant at $\% 1, \% 5$ and $\% 10$. The values in parentheses are the optimal lag length. Maximum lag is 11 . 
As shown in Table 1, all the seasonally unadjusted variables are significant $\mathrm{I}(0)$ at $5 \%$ namely stationary. All variables can be used in the analysis and the predictability of the series is high.

Table 2. ADF test (seasonally adjusted)

\begin{tabular}{|c|c|c|c|}
\hline Variables & None & Intercept & Intercept and Trend \\
\hline$y$ & $-3.96(2)^{\mathrm{a}}$ & $-4.02(2)^{a}$ & $-4.01(2)^{b}$ \\
\hline $\boldsymbol{k}$ & $-3.08(5)^{\mathrm{a}}$ & $-3.17(5)^{b}$ & $-3.20(5)^{\mathrm{c}}$ \\
\hline$l$ & $-1.25(5)$ & $-4.53(1)^{\mathrm{a}}$ & $-4.56(1)^{a}$ \\
\hline$p_{m}^{a}$ & $-0.29(3)$ & $-4.45(1)^{\mathrm{a}}$ & $-4.51(1)^{\mathrm{a}}$ \\
\hline$p_{m}^{u a}$ & $-4.72(2)^{\mathrm{a}}$ & $-4.69(2)^{a}$ & $-2.40(7)$ \\
\hline$p_{y}^{a}$ & $-0.00(11)$ & $-3.25(1)^{b}$ & $-3.17(1)^{\mathrm{c}}$ \\
\hline$p_{y}^{u a}$ & $-1.73(10)^{\mathrm{c}}$ & $-2.38(0)$ & $-2.66(0)$ \\
\hline$p_{y e}^{a}$ & $-0.65(1)$ & $-2.89(1)^{b}$ & $-3.21(1)^{\mathrm{c}}$ \\
\hline$p_{y e}^{u a}$ & $-2.66(0)^{\mathrm{a}}$ & $-2.67(0)^{\mathrm{c}}$ & $-2.58(0)$ \\
\hline$e r_{m}^{a}$ & $-3.03(6)^{\mathrm{a}}$ & $-7.36(0)^{\mathrm{a}}$ & $-7.32(0)^{\mathrm{a}}$ \\
\hline$e r_{m}^{u a}$ & $-2.60(7)^{a}$ & $-2.61(7)^{\mathrm{c}}$ & $-4.50(2)^{\mathrm{a}}$ \\
\hline$e r_{y e}^{a}$ & $-2.82(6)^{\mathrm{a}}$ & $-2.81(6)^{\mathrm{c}}$ & $-6.32(0)^{\mathrm{a}}$ \\
\hline$e r_{y e}^{u a}$ & $-5.30(2)^{\mathrm{a}}$ & $-4.89(2)^{\mathrm{a}}$ & $-3.95(2)^{b}$ \\
\hline
\end{tabular}

Note. a, b, c respectively significant at $\% 1, \% 5$ and $\% 10$. The values in parentheses are the optimal lag length. Maximum lag is 11 .

In Table 2, all the seasonally adjusted variables except $p_{y}^{u a}$ were found to be $\mathrm{I}(0)$ and statistically significant at $5 \%$, so variables are stationary. $p_{y}^{u a}$ was significant at $10 \%$. Again, all the seasonally adjusted variables can be used in the analysis and future values of series can be estimated easily by individuals with rational expectations.

\subsection{Determining the Impact of Anticipated and Unanticipated Expectations on Real Output}

Cobb and Douglas' (1928) Production Function and LASF can be used to determine the effects of anticipated and unanticipated expectations on the level of real output.

\subsubsection{Cobb-Douglas Production Function}

CDPF is one of the most well-known and commonly used production functions. CDPF can be used in investigation of the effect of anticipated and unanticipated inflation on real output. CDPF function can be written as follows.

$$
Y_{t}=A K_{t}^{\beta 1} L_{t}^{\beta 2}
$$

Here $\mathrm{Y}$ is real output, $\mathrm{K}$ is capital, $\mathrm{L}$ is labour, $\beta_{1}$ is the impact of capital on output, $\beta_{2}$ is the effect of labour on output, $\mathrm{A}$ is total factor productivity, and $\mathrm{t}$ is time notation. CDPF indicates that production amount varies depending on capital and labour variables. In order to be able to predict the function, the logarithms of both sides of the equation are taken and the equation is written as follows.

$$
\log Y_{t}=\log A+\beta 1 \log K_{t}+\beta 2 \log L_{t}
$$

Time derivative or difference of both sides is taken to convert the equation to growth equation. In this case the growth equation can be written as follows.

$$
\Delta \log Y_{t}=\Delta \log A+\beta 1 \Delta \log K_{t}+\beta 2 \Delta \log L_{t}
$$

In the equation, $\Delta \log Y$ refers to the growth rate of real output, $\Delta \log K$ to growth rate of capital and $\Delta \log L$ to growth rate of labour. When anticipated and unanticipated expectations are included in the equation,

$$
\Delta \log Y_{t}=\Delta \log A+\beta 1 \Delta \log K_{t}+\beta 2 \Delta \log L_{t}+\delta E\left(p_{t} \mid I_{t-i}\right)+\gamma\left[p_{t}-E\left(p_{t} \mid I_{t-i}\right)\right]
$$

Inflation expectations of $t$ period, estimated with available data set $i$ period before is expressed as $E\left(p_{t} \mid I_{t-i}\right)$, the impact of anticipated expectations on real output as $\delta$, the level of inflation during period $t$ as $p_{t}, t$ period inflation expectation which is unanticipated $i$ terms before as $\left[p_{t}-E\left(p_{t} \mid I_{t-i}\right)\right]$ and the impact of 
unanticipated expectations on real output as $\gamma$. When the equation is rearranged in order to simplify it, we get;

$$
y_{t}=\beta_{0}+\beta 1 k_{t}+\beta 2 l_{t}+\delta p_{t}^{a}+\gamma p_{t}^{u a}+u_{t}
$$

Here, $y_{t}=\Delta \log Y_{t}, \beta_{0}=\Delta \log A, k_{t}=\Delta \log K_{t}, l_{t}=\Delta \log L_{t}, p_{t}^{a}=E\left(p_{t} \mid I_{t-i}\right), p_{t}^{u a}=p_{t}-E\left(p_{t} \mid I_{t-i}\right), u_{t}$ random error term.

In Tables 3 and 4, CDPF is estimated for inflation and exchange rate with seasonally adjusted and unadjusted data.

In Table 3, CDPF is estimated for inflation expectations with both seasonally adjusted data and seasonally unadjusted data. The coefficients of variable $\boldsymbol{k}$ are found to be significant in all the equations while $\boldsymbol{l}$ is significant only for seasonally unadjusted variables. $\boldsymbol{p}_{t}^{\boldsymbol{a}}$ is significant in all the seasonally adjusted equations and for seasonally unadjusted monthly prediction of inflation expectation, and $\boldsymbol{p}_{\boldsymbol{t}}^{\boldsymbol{u a}}$ is statistically insignificant in all the equations.

Crisis dummy is statistically more significant in seasonally adjusted data than seasonally unadjusted one. No equation includes autocorrelation however it can be seen in the table that seasonal adjustment reduces coefficients of determination in equations and disrupts homoscedasticity and normal distribution. Whether it is estimated using seasonally adjusted or seasonally unadjusted data, in all cases any evidence supporting PIP could not be found.

Table 3. CDPF with inflation expectation

\begin{tabular}{|c|c|c|c|c|c|c|}
\hline \multirow{2}{*}{ Variables } & \multicolumn{3}{|c|}{ Seasonally Unadjusted } & \multicolumn{3}{|c|}{ Seasonally Adjusted } \\
\hline & $E\left(p_{t} \mid I_{t-1}\right)$ & $E\left(p_{t} \mid I_{t-12}\right)$ & $E\left(p_{t} \mid I_{y e}\right)$ & $E\left(p_{t} \mid I_{t-1}\right)$ & $E\left(p_{t} \mid I_{t-12}\right)$ & $E\left(p_{t} \mid I_{y e}\right)$ \\
\hline \multirow{2}{*}{$\boldsymbol{k}$} & $0.9266^{\mathrm{a}}$ & $0.9332^{\mathrm{a}}$ & $0.9342^{\mathrm{a}}$ & $0.3078^{\mathrm{a}}$ & $0.3014^{\mathrm{a}}$ & $0.3015^{\mathrm{a}}$ \\
\hline & $(25.30)$ & $(24.75)$ & $(24.88)$ & $(9.01)$ & $(9.18)$ & $(9.14)$ \\
\hline \multirow{2}{*}{$l$} & $-0.5035^{\mathrm{c}}$ & $-0.5902^{\mathrm{b}}$ & $-0.5583^{\mathrm{b}}$ & 0.2940 & 0.1107 & 0.0714 \\
\hline & $(-1.94)$ & $(-2.30)$ & $(-2.16)$ & $(0.65)$ & $(0.25)$ & $(0.17)$ \\
\hline \multirow{2}{*}{$p_{t}^{a}$} & $0.0182^{\mathrm{b}}$ & 0.0053 & 0.0031 & $-0.0228^{b}$ & $-0.0068^{\mathrm{a}}$ & $-0.0044^{\mathrm{a}}$ \\
\hline & $(2.11)$ & $(1.31)$ & $(1.46)$ & $(-2.52)$ & $(-2.86)$ & $(-3.63)$ \\
\hline \multirow{2}{*}{$p_{t}^{u a}$} & -0.0062 & -0.0022 & -0.0002 & -0.0012 & -0.0014 & -0.0011 \\
\hline & $(-1.36)$ & $(-1.32)$ & $(-0.09)$ & $(-0.35)$ & $(-1.46)$ & $(-1.12)$ \\
\hline \multirow{2}{*}{$D_{c}$} & -0.0192 & $-0.0256^{\mathrm{c}}$ & $-0.0232^{c}$ & $-0.0335^{\mathrm{a}}$ & $-0.0251^{\mathrm{a}}$ & $-0.0287^{\mathrm{a}}$ \\
\hline & $(-1.46)$ & $(-1.93)$ & $(-1.76)$ & $(-4.33)$ & $(-3.34)$ & $(-3.87)$ \\
\hline \multirow{2}{*}{ C } & -0.0092 & -0.0295 & -0.0210 & $0.0187^{\mathrm{a}}$ & $0.0526^{\mathrm{a}}$ & $0.0387^{\mathrm{a}}$ \\
\hline & $(-1.39)$ & $(-1.08)$ & $(-1.21)$ & (2.99) & (3.29) & (3.92) \\
\hline $\mathbf{R}^{2}$ & 0.90 & 0.90 & 0.90 & 0.62 & 0.65 & 0.65 \\
\hline DW & 2.32 & 2.31 & 2.26 & 1.91 & 2.10 & 2.00 \\
\hline \multirow{2}{*}{ LM } & 2.35 & 2.05 & 1.58 & 0.16 & 1.00 & 0.25 \\
\hline & {$[0.13]$} & {$[0.15]$} & {$[0.21]$} & {$[0.69]$} & {$[0.32]$} & {$[0.62]$} \\
\hline \multirow{2}{*}{ ARCH } & 0.67 & 0.16 & 0.13 & 10.23 & 6.57 & 4.70 \\
\hline & {$[0.42]$} & {$[0.69]$} & {$[0.72]$} & {$[0.00]$} & {$[0.01]$} & {$[0.03]$} \\
\hline \multirow{2}{*}{ JB } & 3.25 & 1.58 & 1.53 & 31.10 & 36.19 & 38.19 \\
\hline & {$[0.20]$} & {$[0.46]$} & {$[0.47]$} & {$[0.00]$} & {$[0.00]$} & {$[0.00]$} \\
\hline $\mathbf{n}$ & 83 & 83 & 83 & 83 & 83 & 83 \\
\hline
\end{tabular}

Note. a, b, c respectively significant at $\% 1, \% 5$ and $\% 10$. The values in parentheses are calculated $\mathrm{t}$ statistics. The values in square brackets are probability values. Crisis dummy $D_{c}$ has been added to the equations. 
Table 4. CDPF with exchange rate expectation

\begin{tabular}{|c|c|c|c|c|}
\hline \multirow{2}{*}{ Variables } & \multicolumn{2}{|c|}{ Seasonally Unadjusted } & \multicolumn{2}{|c|}{ Seasonally Adjusted } \\
\hline & $E\left(e r_{t} \mid I_{t-1}\right)$ & $E\left(e r_{t} \mid I_{y e}\right)$ & $E\left(e r_{t} \mid I_{t-1}\right)$ & $E\left(e r_{t} \mid I_{y e}\right)$ \\
\hline \multirow{2}{*}{$\boldsymbol{k}$} & $0.9212^{\mathrm{a}}$ & $0.9186^{\mathrm{a}}$ & $0.3162^{\mathrm{a}}$ & $0.3137^{\mathrm{a}}$ \\
\hline & (25.35) & $(24.62)$ & $(9.05)$ & $(9.11)$ \\
\hline \multirow{2}{*}{$l$} & $-0.6417^{b}$ & $-0.5212^{b}$ & 0.2658 & 0.2930 \\
\hline & $(-2.52)$ & $(-1.96)$ & $(0.57)$ & $(0.63)$ \\
\hline \multirow{2}{*}{$e r_{t}^{a}$} & $0.1640^{\mathrm{b}}$ & -0.0191 & -0.0607 & $-0.1133^{b}$ \\
\hline & $(2.26)$ & $(-0.21)$ & $(-1.29)$ & $(-2.00)$ \\
\hline \multirow{2}{*}{$e r_{t}^{u a}$} & -0.0002 & 0.0005 & 0.0001 & 0.0001 \\
\hline & $(-0.61)$ & $(1.29)$ & $(0.03)$ & $(-0.01)$ \\
\hline \multirow{2}{*}{$D_{c}$} & $-0.0276^{\mathrm{b}}$ & $-0.0228^{c}$ & $-0.0283^{\mathrm{a}}$ & $-0.0288^{\mathrm{a}}$ \\
\hline & $(-2.11)$ & $(-1.70)$ & $(-3.61)$ & $(-3.76)$ \\
\hline \multirow{2}{*}{ C } & 0.0029 & 0.0037 & $0.0036^{\mathrm{c}}$ & $0.0037^{\mathrm{c}}$ \\
\hline & $(1.00)$ & $(1.23)$ & (1.73) & $(1.81)$ \\
\hline $\mathbf{R}^{2}$ & 0.90 & 0.90 & 0.60 & 0.61 \\
\hline DW & 2.25 & 2.24 & 1.85 & 1.86 \\
\hline \multirow{2}{*}{ LM } & 1.43 & 1.27 & 0.00004 & 0.0016 \\
\hline & $(0.24)$ & $(0.26)$ & (0.99) & $(0.97)$ \\
\hline \multirow{2}{*}{ ARCH } & 1.68 & 0.24 & 5.67 & 4.07 \\
\hline & $(0.20)$ & $(0.62)$ & $(0.02)$ & $(0.05)$ \\
\hline \multirow{2}{*}{ JB } & 1.39 & 1.65 & 33.86 & 28.51 \\
\hline & $(0.50)$ & $(0.44)$ & $(0.00)$ & $(0.00)$ \\
\hline $\mathbf{n}$ & 83 & 83 & 83 & 83 \\
\hline
\end{tabular}

Note. a, b, c respectively significant at $\% 1, \% 5$ and $\% 10$. The values in parentheses are $\mathrm{t}$ statistics. The values in square brackets are probability values. Crisis dummy $D_{c}$ has been added to the equations.

Cobb-Douglas Production equations have been estimated for Exchange Rate Expectation in Table 4. Similar results with Table 3 were obtained in anticipated and unanticipated Exchange Rate Expectation for one month before and the year-end. Consequently PIP is rejected.

\subsubsection{Lucas Aggregate Supply Function}

Lucas (1973) suggested that a change in the level of real output basically occurs only in an unanticipated change, namely in case of a surprise, and described this with the following equation.

$$
\begin{gathered}
y_{t}=\alpha+\gamma\left[p_{t}-E\left(p_{t} \mid I_{t-i}\right)\right]+\lambda y_{t-1}+\varepsilon_{t}|\lambda|<1 \\
y_{t}=\alpha+\gamma p_{t}^{u a}+\lambda y_{t-1}+\varepsilon_{t}
\end{gathered}
$$

Here $y_{t}$ and $y_{t-1}$ respectively refer to change in real production level in $t$ and $t-1$ period, $p_{t}$ to inflation level in $\mathrm{t}$ period, $p_{t}^{u a}$ to unanticipated expectations, $\alpha, \gamma$ and $\lambda$ to coefficients of equation, and $\varepsilon_{t}$ to random error term. In this model, it is stated that whether unanticipated expectations are effective on real output can be investigated.

In Tables 5 and 6, LASF is estimated for inflation and exchange rate with seasonally adjusted and unadjusted data.

When the equations estimated for LASF are examined, it is seen that except for seasonally adjusted estimation for the 12 months before, in all the equations, unanticipated inflation expectations are statistically insignificant, so PIP is not supported. In general, although one lag of the dependent variable takes part on the right side of the equation as the dependent variable, the problem of autocorrelation has been seen. Although problems of heteroscedasticity and normal distribution do not occur in estimations formed with seasonally unadjusted variables, problems of heteroscedasticity and normal distribution are experienced in estimations with seasonally adjusted variables. However, the crisis dummy variable has gained significance at higher levels in seasonally unadjusted equations. Coefficients of determination of equations decreased significantly in LASF. 
Table 5. LASF with inflation expectation

\begin{tabular}{cllllll}
\hline \multirow{2}{*}{ Variables } & \multicolumn{3}{c}{ Seasonally Unadjusted } & \multicolumn{3}{c}{ Seasonally Adjusted } \\
\cline { 2 - 7 } & $E\left(p_{t} \mid I_{t-1}\right)$ & $E\left(p_{t} \mid I_{t-12}\right)$ & $E\left(p_{t} \mid I_{\text {ye }}\right)$ & $E\left(p_{t} \mid I_{t-1}\right)$ & $E\left(p_{t} \mid I_{t-12}\right)$ & $E\left(p_{t} \mid I_{\text {ye }}\right)$ \\
\hline \multirow{2}{*}{$\boldsymbol{y}_{\boldsymbol{t}-\mathbf{1}}$} & $-0.4151^{\mathrm{a}}$ & $-0.4191^{\mathrm{a}}$ & $-0.4187^{\mathrm{a}}$ & -0.0705 & -0.1342 & -0.0623 \\
& $(-4.00)$ & $(-4.03)$ & $(-4.03)$ & $(-0.63)$ & $(-1.21)$ & $(-0.55)$ \\
$\boldsymbol{p}_{\boldsymbol{t}}^{\boldsymbol{u a}}$ & 0.0075 & -0.0027 & 0.0032 & -0.0010 & $-0.0033^{\mathrm{b}}$ & -0.0006 \\
& $(0.63)$ & $(-0.60)$ & $(0.69)$ & $(-0.21)$ & $(-2.44)$ & $(-0.41)$ \\
$\boldsymbol{D}_{\boldsymbol{c}}$ & $-0.0717^{\mathrm{c}}$ & $-0.0750^{\mathrm{b}}$ & $-0.0700^{\mathrm{c}}$ & $-0.0437^{\mathrm{a}}$ & $-0.0475^{\mathrm{a}}$ & $-0.0440^{\mathrm{a}}$ \\
& $(-1.91)$ & $(-2.01)$ & $(-1.86)$ & $(-3.70)$ & $(-4.15)$ & $(-3.72)$ \\
$\mathbf{C}$ & 0.0105 & 0.0150 & 0.0090 & $0.0057^{\mathrm{b}}$ & $0.0112^{1}$ & $0.0060^{\mathrm{b}}$ \\
$\mathbf{R}^{2}$ & $(1.30)$ & $(1.39)$ & $(1.07)$ & $(2.30)$ & $(3.41)$ & $(2.33)$ \\
DW & 0.19 & 0.19 & 0.19 & 0.16 & 0.22 & 0.16 \\
& 2.09 & 2.08 & 2.09 & 1.70 & 1.67 & 1.70 \\
$\mathbf{L} \mathbf{L M}$ & 3.54 & 3.33 & 3.31 & 15.26 & 11.09 & 15.47 \\
& $(0.06)$ & $(0.07)$ & $(0.07)$ & $(0.00)$ & $(0.00)$ & $(0.00)$ \\
ARCH & 0.46 & 0.64 & 0.42 & 3.70 & 2.84 & 3.83 \\
& $(0.50)$ & $(0.43)$ & $(0.52)$ & $(0.06)$ & $(0.10)$ & $(0.05)$ \\
JB & 1.15 & 1.64 & 1.16 & 506 & 514 & 471 \\
& $(0.56)$ & $(0.44)$ & $(0.56)$ & $(0.00)$ & $(0.00)$ & $(0.00)$ \\
$\mathbf{n}$ & 82 & 82 & 82 & 82 & 82 & 82 \\
\hline
\end{tabular}

Note. a, b, c respectively significant at $\% 1, \% 5$ and $\% 10$. The values in parentheses are t statistics. The values in square brackets are probability values. Crisis dummy $D_{c}$ has been added to the equations.

Table 6. LASF with exchange rate expectation

\begin{tabular}{|c|c|c|c|c|}
\hline \multirow{2}{*}{ Variables } & \multicolumn{2}{|c|}{ Seasonally Unadjusted } & \multicolumn{2}{|c|}{ Seasonally Adjusted } \\
\hline & $E\left(e r_{t} \mid I_{t-1}\right)$ & $E\left(e r_{t} \mid I_{y e}\right)$ & $E\left(e r_{t} \mid I_{t-1}\right)$ & $E\left(e r_{t} \mid I_{y e}\right)$ \\
\hline \multirow{2}{*}{$y_{t-1}$} & $-0.4133^{\mathrm{a}}$ & $-0.4162^{a}$ & -0.0724 & -0.0808 \\
\hline & $(-3.93)$ & $(-3.96)$ & $(-0.65)$ & $(-0.69)$ \\
\hline \multirow{2}{*}{$e r_{t}^{u a}$} & -0.0002 & -0.0001 & -0.0001 & 0.0005 \\
\hline & $(-0.15)$ & $(-0.04)$ & $(-0.11)$ & $(0.27)$ \\
\hline \multirow{2}{*}{$D_{c}$} & $-0.0740^{c}$ & $-0.0740^{c}$ & $-0.0436^{\mathrm{a}}$ & $-0.0441^{\text {a }}$ \\
\hline & $(-1.98)$ & $(-1.97)$ & $(-3.69)$ & $(-3.68)$ \\
\hline \multirow{2}{*}{$\mathbf{C}$} & 0.0106 & 0.0107 & $0.0057^{b}$ & $0.0058^{b}$ \\
\hline & $(1.29)$ & $(1.30)$ & $(2.30)$ & $(2.31)$ \\
\hline $\mathbf{R}^{2}$ & 0.18 & 0.18 & 0.16 & 0.16 \\
\hline DW & 2.09 & 2.08 & 1.69 & 1.70 \\
\hline \multirow{2}{*}{$\mathbf{L M}$} & 3.53 & 3.22 & 16.29 & 15.94 \\
\hline & $(0.06)$ & $(0.08)$ & $(0.00)$ & $(0.00)$ \\
\hline \multirow{2}{*}{ ARCH } & 0.56 & 0.57 & 3.64 & 3.49 \\
\hline & $(0.46)$ & $(0.46)$ & $(0.06)$ & $(0.07)$ \\
\hline \multirow{2}{*}{ JB } & 1.44 & 1.46 & 494 & 488 \\
\hline & $(0.49)$ & $(0.48)$ & $(0.00)$ & $(0.00)$ \\
\hline $\mathbf{n}$ & 82 & 82 & 82 & 82 \\
\hline
\end{tabular}

Note. a, b, c respectively significant at $\% 1, \% 5$ and $\% 10$. The values in parentheses are $t$ statistics. The values in square brackets are probability values. Crisis dummy $D_{c}$ has been added to the equations.

Almost the same results were obtained in the equations, estimated for exchange rate. In general, efficient results could not be achieved with LASF.

\subsubsection{VAR and Impulse Response}

Lucas (1986) has stated that economic agents are dependent to economic output of the adaptive learning process until they collect enough information about the economy. Orphanides and Williams (2005) said that they can model the expectations of economic agents in the form of a VAR system. Whether lagged values of policy variables are significant is investigated in the studies of McGee and Stasiak (1985), Marashdeh (1993), Yamak 
and Kücükkale (1998), Peker (2007), Khan (2008), Komijani et al. (2012). In this study, the significance of the lagged effects of anticipated and unanticipated expectations is investigated by the VAR analysis. In addition, the effects of shocks in expectation variables on the real variables of investigated using impulse response analysis are investigated.

Sims (1980) was the first to develop the VAR analysis. According to Sims (1980), grouping the variables as endogenous and exogenous is not required. Therefore all of the variables in the VAR analysis are accepted as endogenous. For example; a VAR model with $y_{t}, p_{t}^{a}, p_{t}^{u a}$ variables can be displayed as follows.

$$
\left[\begin{array}{c}
y_{t} \\
p_{t}^{a} \\
p_{t}^{u a}
\end{array}\right]_{k x 1}=\left[\begin{array}{c}
A_{10} \\
A_{20} \\
A_{30}
\end{array}\right]_{k x 1}+\left[\begin{array}{lll}
A_{11}(L) & A_{12}(L) & A_{13}(L) \\
A_{21}(L) & A_{22}(L) & A_{23}(L) \\
A_{31}(L) & A_{32}(L) & A_{33}(L)
\end{array}\right]_{k x k}\left[\begin{array}{c}
y_{t} \\
p_{t}^{a} \\
p_{t}^{u a}
\end{array}\right]_{k x 1}+\left[\begin{array}{c}
e_{1 t} \\
e_{2 t} \\
e_{3 t}
\end{array}\right]_{k x 1}
$$

Here, $A_{i j}$ is the independent variable coefficient, $\mathrm{k}$ is the number of variables in the VAR system, so that here $\mathrm{k}$ is $3, L$ is lag operator, $\mathrm{t}$ is time notation $(t=1, \ldots \ldots, T)$, and $e_{i t}$ is random error terms of equations. In VAR analysis both the variables used in the analysis and VAR system should be stationary. Stationarity of the variables was investigated by the ADF test. All the variables are stationary and can be used in VAR systems. Stationarity of all VAR systems was examined with inverse roots of AR characteristic polynomial and all systems were found to be stationary. The length of the lag in the VAR system is calculated using Final Prediction Error (FPE) information criterion.

The dependent variable in the first equation is $y_{t}$. For example, collectively, significance of lagged coefficients of $p_{t}^{a}$ variable can be tested with $H_{01}: A_{12}(L)=0$. Collective significance of lagged coefficients of $p_{t}^{u a}$ variable on the other hand can be tested with $H_{02}: A_{13}(L)=0 . \chi^{2}$ or F-tests can be used for testing these hypotheses. $\chi^{2}$ was used in this study. If $H_{01}$ is rejected, it is concluded that anticipated expectations are effective on real variables; if $H_{01}$ is not rejected then they are not effective. If $H_{02}$ is rejected it is accepted that unanticipated expectations are effective on real variables; if $H_{02}$ is not rejected they are not effective. If anticipated expectations are effective on real variables or unanticipated expectations are not effective on real variables, then the PIP hypothesis would have been rejected.

Table 7. VAR without dummy crisis

\begin{tabular}{lllll}
\hline \multirow{2}{*}{ Variables } & \multicolumn{2}{c}{ Seasonally Unadjusted } & \multicolumn{2}{c}{ Seasonally Adjusted } \\
\cline { 2 - 5 } & $H_{01}: A_{12}(L)=\mathbf{0}$ & $H_{02}: A_{13}(L)=\mathbf{0}$ & $H_{01}: A_{12}(L)=\mathbf{0}$ & $H_{02}: A_{13}(L)=\mathbf{0}$ \\
\hline$E\left(p_{t} \mid I_{t-1}\right)$ & $20.49(3)^{\mathrm{a}}$ & $4.27(3)$ & $2.35(1)$ & $0.07(1)$ \\
$E\left(p_{t} \mid I_{t-12}\right)$ & $8.33(2)^{\mathrm{b}}$ & $0.90(2)$ & $12.36(2)^{\mathrm{a}}$ & $0.15(2)$ \\
$E\left(p_{t} \mid I_{y e}\right)$ & $7.99(1)^{\mathrm{a}}$ & $0.03(1)$ & $11.11(1)^{\mathrm{a}}$ & $1.20(1)$ \\
$E\left(e r_{t} \mid I_{t-1}\right)$ & $2.84(1)^{\mathrm{c}}$ & $3.81(1)^{\mathrm{b}}$ & $8.35(1)^{\mathrm{a}}$ & $0.03(1)$ \\
$E\left(e r_{t} \mid I_{y e}\right)$ & $4.90(1)^{\mathrm{b}}$ & $1.40(1)$ & $12.79(1)^{\mathrm{a}}$ & $0.06(1)$ \\
\hline
\end{tabular}

Note. Coefficients are $\chi^{2}$ statistic value calculated for hypotheses. a, b, c respectively significant at $\% 1, \% 5$ and $\% 10$. The values in parentheses are optimal lag length of VAR system. Maximum lag is 6 .

The rows in Table 7 and Table 8, respectively, refer to a month before the time period t for inflation, twelve months before and the end of the year expectations, and a month before the time period $t$ for exchange rate and the end of the year expectations. VAR equations including anticipated and unanticipated expectations were estimated for each of these expectation periods. Columns on the other hand include $\chi^{2}$ values calculated for $\mathrm{H}_{01}$ and $\mathrm{H}_{02}$ hypotheses. Table 7 shows the results of the VAR equation which does not include the Crisis dummy, while the results in Table 8 show the VAR equation including the Crisis dummy. As seen in Table 7, whether seasonally adjusted or not, in general coefficients of anticipated expectations are collectively found to be significant. Coefficients of both anticipated and unanticipated expectations for monthly exchange rate expectations were found to be statistically significant. The results do not support the PIP. 
Table 8. VAR with dummy crisis

\begin{tabular}{lllll}
\hline \multirow{2}{*}{ Variables } & \multicolumn{3}{c}{ Seasonally Unadjusted } & \multicolumn{2}{c}{ Seasonally Adjusted } \\
\cline { 2 - 5 } & $H_{01}: A_{12}(L)=\mathbf{0}$ & $H_{02}: A_{13}(L)=\mathbf{0}$ & $H_{01}: A_{12}(L)=\mathbf{0}$ & $H_{02}: A_{13}(L)=\mathbf{0}$ \\
\hline$E\left(p_{t} \mid I_{t-1}\right)$ & $26.24(5)^{\mathrm{a}}$ & $13.51(5)^{\mathrm{b}}$ & $5.18(1)^{\mathrm{b}}$ & $2.25(1)$ \\
$E\left(p_{t} \mid I_{t-12}\right)$ & $4.54(2)$ & $1.67(2)$ & $17.07(3)^{\mathrm{a}}$ & $3.88(3)$ \\
$E\left(p_{t} \mid I_{y e}\right)$ & $6.59(1)^{\mathrm{a}}$ & $0.001(1)$ & $11.17(1)^{\mathrm{a}}$ & $3.09(1)^{\mathrm{c}}$ \\
$E\left(e r_{t} \mid I_{t-1}\right)$ & $1.37(1)$ & $4.31(1)^{\mathrm{b}}$ & $--(0)$ & $--(0)$ \\
$E\left(e r_{t} \mid I_{y e}\right)$ & $2.85(1)^{\mathrm{c}}$ & $1.10(1)$ & $9.48(1)^{\mathrm{a}}$ & $0.11(1)$ \\
\hline
\end{tabular}

Note. Coefficients are $\chi^{2}$ statistic value calculated for hypotheses. a, b, c respectively significant at $\% 1$, $\% 5$ and $\% 10$. The values in parentheses are optimal lag length of VAR system. Maximum lag is 6.

In the case of the addition of the Crisis dummy to equations, almost the same results were obtained. Conversely, when seasonal adjustment is applied for the monthly exchange rate expectation, optimal lag length of the variables became zero and as a result VAR could not be estimated. In results including seasonally unadjusted monthly exchange rate expectations, coefficients for anticipated expectations compatible with the ineffectiveness of the policy are found to be insignificant, and for unanticipated expectations they are significant; however first-degree autocorrelation is found in equations. In overall evaluation of Table 8, PIP is rejected.

Impulse-response analysis shows how the other variables respond to innovation or shock in the variables in the VAR system. The VAR system can be written in a different way as follows;

$$
X_{t}=A_{0}+A_{1} X_{t-1}+A_{2} X_{t-2}+\ldots . .+A_{m} X_{t-m}+e_{t}
$$

Here, $X_{t}$ represents a vector of $k x 1$ (3x1) size formed of $y_{t}, p_{t}^{a}, p_{t}^{u a}$ variables, $A_{0}$ is constant term vector in $k x 1$ size, $A_{i}$ is coefficients matrix in size of $k x k$ (for every $\left.i=1, \ldots m\right), m$ is optimal lag, and $e_{t}$ is random error terms in size of $k x 1$.

VAR system can be written as $M A(\infty)$ as follows,

$$
X_{t}=\mu+\sum_{s=0}^{\infty} \Phi_{s} e_{t-s}=\mu+\Phi_{0} e_{t}+\Phi_{1} e_{t-1}+\Phi_{2} e_{t-2}+\Phi_{3} e_{t-3}
$$

and impulse-response function can be written as follows;

$$
\Phi_{n}=\frac{\partial X_{i, t+n}}{\partial e_{j, t}}
$$

The equation expresses response of variable $i$ in period $t+n$ to one-time innovation or shock on variable $j$ in period t. The following figures show the responses of variable $i$ to Cholesky one standard deviation innovation or shock on variable $\mathrm{j}$ with \pm 2 standard error. Statistically significant impulse-responses are given in Figure 2 and Figure 3 .

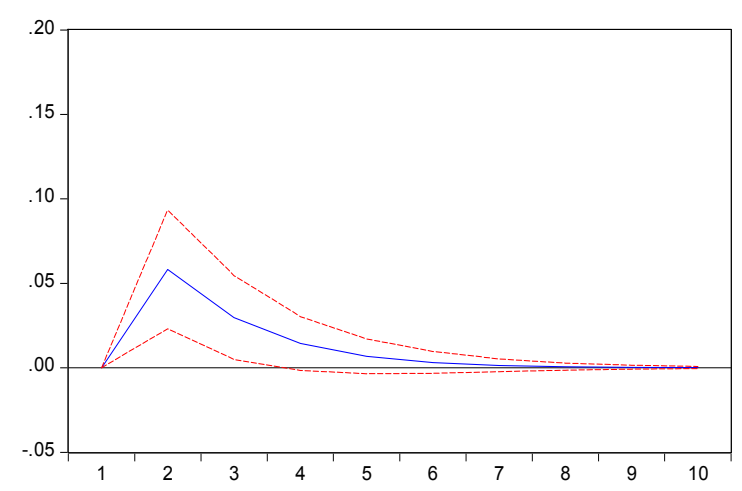

Figure 2a. Response of $p_{t}^{a}$ to $p_{t}^{u a}$ on $E\left(p_{t} \mid I_{t-1}\right)$ 


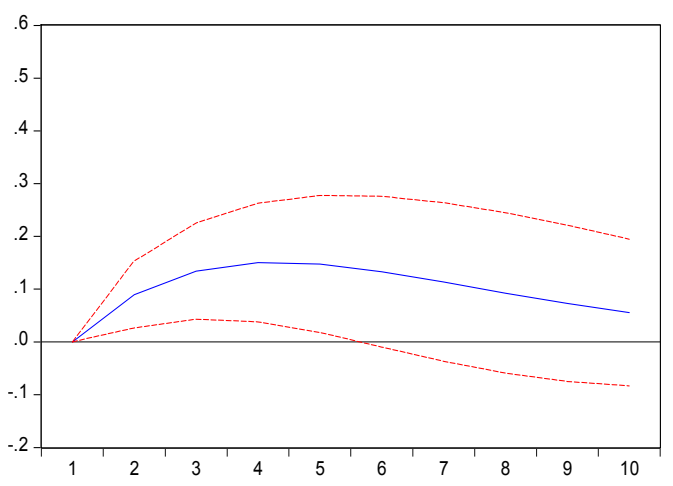

Figure $2 b$. Response of $p_{t}^{a}$ to $p_{t}^{\text {ua }}$ on $E\left(p_{t} \mid I_{t-12}\right)$

Figure 2 shows that in both one month and twelve months before, any innovation or shock that occurs in unanticipated expectations results in an increase of anticipated expectations of inflation. This reaction represents the process of adaptation of expectations to the shock for the last three periods in monthly expectations, for the five periods in annual expectations and then blurs. When it is considered that unanticipated and anticipated expectations are complementary to each other in the event of new information entry to available information set, it is normally expected that anticipated inflation updates itself.

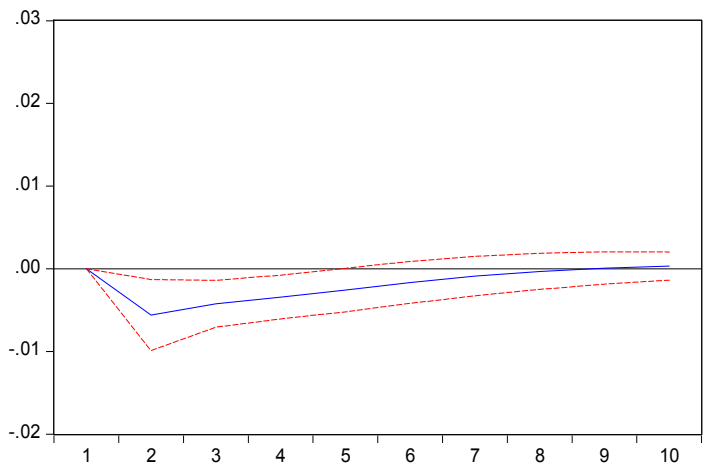

Figure $3 \mathrm{a}$. Response of $y_{t}$ to $p_{t}^{a}$ on $E\left(p_{t} \mid I_{t-12}\right)$

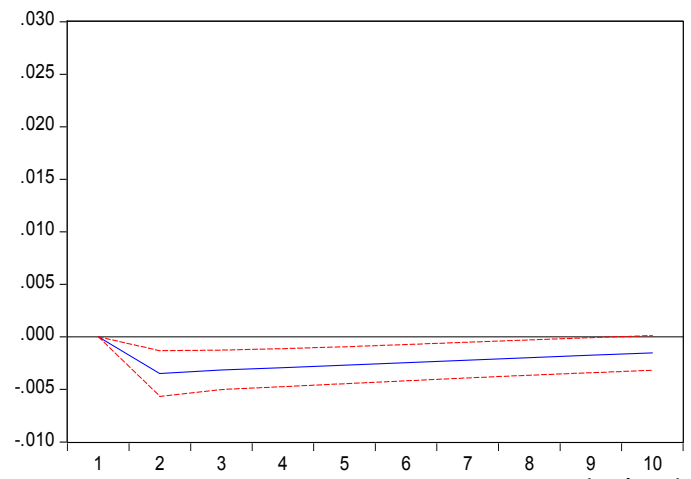

Figure $3 \mathrm{~b}$. Response of $y_{t}$ to $p_{t}^{a}$ on $E\left(p_{t} \mid I_{y e}\right)$

Real output response to an innovation or shock occur sin anticipated expectations with decline. This situation can be interpreted as where, in the event of a sudden increase in inflation expectations, real production tends to decline. The impact of this shock on real output lasts for five months in twelve-month inflation expectations and seven months in year-end inflation expectation. In the event of information flow to the existing information set about anticipated expectations, namely a sudden update in expectations of economic agent, the adaptation of the real sector to this update can be said to take about five to eight months. 


\section{Conclusion}

According to the PIP suggested by Lucas (1973) and Sargent and Wallace (1975), only unanticipated changes in expectations will affect real economic variables. In this study, the PIP hypothesis has been investigated for the study period in which inflation targeting policy which retained transparency and accountability in terms of monetary policy at the forefront is implemented using both seasonally adjusted and seasonally unadjusted data with CDPF, LASF, VAR and Impulse-Response analysis.

A survey of expectations conducted by the CBRT has been taken as the anticipated expectation series. Anticipated expectations are modified mean of one month before, twelve months before and year-end survey expectations of inflation rate of CPI and one month before, and year-end estimations of the exchange rate. Unanticipated expectations are the difference in anticipated expectations from the realization values. Stationarity of the variables used in the study is examined with the ADF unit root test. All the seasonally unadjusted and adjusted variables are stationary at I(0) level. All variables can be used in the analysis and can be estimated easily by individuals with rational expectations.

The simultaneous effect of anticipated and unanticipated expectations of inflation and exchange rate on real output was tested with CDPF. In general, the results obtained from CDPF do not support the PIP. The results of LASF which tests the simultaneous effect of unanticipated expectations of inflation and exchange rate on real output equations do not support the PIP either. Also, the overall evaluation shows that seasonal adjustment decreases coefficients of determination of the estimated equations, and normal distribution and homoscedasticity is adversely affected.

The results of VAR analysis taking lagged variables of anticipated and unanticipated expectations of inflation and exchange rate on real output into account confirm that coefficients of anticipated expectations and some unanticipated expectations are statistically significant and acceptable. The results of impulse-response analysis have demonstrated that any innovation or shock that occurred in unanticipated expectations led to an increase in anticipated expectations of inflation. In addition, in the event of innovation or shock in the existing information set about anticipated expectations of economic agents, namely a sudden information input to the existing information set, it can be said that it takes between five and eight months for the real sector to adapt to this update. The results of VAR and Impulse-Response analysis also do not support the PIP. These results are compatible with the studies of Yamak and Kucukkale (1998), Peker (2007), Altunoz (2014), ve Tuğcu (2015).

Overall evaluation of the study suggests that the results obtained on the basis of anticipated and unanticipated expectation series calculated using surveys conducted by the Central Bank with seasonally adjusted and unadjusted data under the inflation targeting policy implemented during the study period do not support the PIP.

\section{References}

Abaan, E. D. (1987). Parasal sok ve reel ekonomik etkinlik. METU Studies in Development, 14(3), 271-282.

Altunoz, U. (2014). Validity the quantity theory of money for Turkish economy. Global Journal for Research Analysis, 3(8), 51-53. http://dx.doi.org/10.15373/222/22778160

Bade, R., \& Parkin, M. (1978). Central bank laws and monetary policies: A preliminary investigation. In M. Porter (Ed.), The Australian monetary system in the 1970s, Monash University (pp. 24-39).

Barro, R. J. (1977). Unanticipated money growth and unemployment in the United States. American Economic Review, 67(1), 101-115.

Barro, R. J. (1978). Unanticipated money, output and the price level in the United States. Journal of Political Economy, 86(4), 549-580. http://dx.doi.org/10.1086/260699

Batchelor, R. A., \& Sherrif, T. D. (1980). Unemployment and unanticipated inflation in postwar Britain. Economica, 47(186), 179-192. http://dx.doi.org/10.2307/2553235

Begum, N. (1997). Money and economic activity in Bangladesh: A rational expectations approach. The Bangladesh Development Studies, 25(3), 73-97. http://dx.doi.org/10.2307/40795580

Bernanke, B. S., Laubach, T., Mishkin, F. S., \& Posen, A. S. (1999). Inflation targeting: Lessons from the international experience. Princeton, NJ: Princeton University Press.

Berument, H., Ceylan, N. B., \& Olgun, H. (2007). The effects of changes in the anticipated and unanticipated fed funds target rate on financial indicators: The case of an emerging market country-Turkey. International Research Journal of Finance and Economics, 7, 40-47.

Berument, H., \& Ceylan, N. B. (2010). The effects of anticipated and unanticipated federal funds target rate 
changes on domestic interest rates: international evidence International. Review of Applied Financial Issues and Economics, 2(2), 328-340.

Bilgili, F. (1999). Analysis of anticipated and unanticipated monetary policies in the framework of rational expectations hypothesis. Iktisat Isletme and Finans Journal, 14(163), 40-57. http://dx.doi.org/10.3848/iif.1999.163.9584

Canarella, G., \& Pollard, S. K. (1989). Unanticipated monetary growth, output, and the price level in Latin America. Journal of Development Economics, 30(2), 345-358. http://dx.doi.org/10.1016/0304-3878(89)90008-4

CBRT. (2013). Methodological information on the survey of expectations. Department of statistics, real sector data division. Retrieved from http://www.tcmb.gov.tr/ikt-yonelim/beklenti/SE-Methodology.pdf

Chu, J., \& Ratti, R. A. (1997). Effects of unanticipated monetary policy on aggregate Japanese output: The role of positive and negative shocks. Canadian Journal of Economics, 30(3), 722-741. http://dx.doi.org/10.2307/136241

Cobb, C. W., \& Douglas, P. H. (1928). A theory of production. American Economic Review, 18(1), 139-165. http://dx.doi.org/10.1111/j.1540-6261.1977.tb03324.x

Cochrane, J. H. (1998). What do the VARs mean? Measuring the output effects of monetary policy. Journal of Monetary Economics, 41(2), 277-300. http://dx.doi.org/10.1016/S0304-3932(97)00075-5

Cover, J. P. (1992). Asymmetric effects of positive and negative money-supply shocks. Quarterly Journal of Economics, 107(4), 1201-1282. http://dx.doi.org/10.2307/2118388

Darrat, A. F. (1985). Anticipated money and real output in Italy: Some tests of a rational expectations approach. Journal of Post Keynesian Economics, 8(1), 81-90.

Dickey, D. A., \& Fuller, W. A. (1979). Distribution of the estimators for autoregressive time series with a unit root. Journal of the American Statistical Association, 74(366), 427-431. http://dx.doi.org/10.1080/01621459.1979.10482531

Dickey, D. A., \& Fuller, W. A. (1981). The likelihood ratio statistics for autoregressive time series with a unit root. Econometrica, 49(4), 1057-1072. http://dx.doi.org/10.2307/1912517

Fisher, M. E., \& Seater, J. J. (1993). Long run neutrality and super neutrality in an ARIMA framework. The American Economic Review, 83, 402-415.

Hasanov, M. (2006). The effects of anticipated and unanticipated monetary policy on real output: The case of Turkey. Gazi University Journal of Economics and Administrative Sciences, 8(3), 17-36.

Hatemi-J, A. (2008). Tests for cointegration with two unknown regime shifts: With an application to financial market integration. Empirical Economics, 35, 497-505. http://dx.doi.org/10.1007/s00181-007-0175-9

Huchet, M. (2003). Does single monetary policy have asymmetric real effects in EMU? Journal of Policy Modeling, 25(2), 151-178. http://dx.doi.org/10.1016/S0161-8938(02)00204-1

Karras, G. (1996). Are the output effects of money supply shocks asymmetric? Convex aggregate supply or pushing on a string? Journal of Macroeconomics, 18(4), 605-619. http://dx.doi.org/10.1016/S0164-0704(96)80054-1

Karras, G., \& Stokes, H. H. (1999). Why are the effects of money-supply shocks asymmetric? Evidence from prices, consumption, and investment. Journal of Macroeconomics, 21(4), 713-727. http://dx.doi.org/10.1016/S0164-0704(99)80003-2

Khan, H. M. (2008). Short run effects of an unanticipated change in monetary policy: Interpreting macroeconomic dynamics in Pakistan. SBP Research Bulletin, 4(1), 1-29.

Klomp, J., \& De Haan, J. (2010). Inflation and central cank independence: A meta regression analysis. Journal of Economic Surveys, 24, 593-621. http://dx.doi.org/10.1111/j.1467-6419.2009.00597.x

Komijani, A., Sargolzaei, M., Ahmad, R., \& Ahmadi, M. (2012). Asymmetric effects of monetary shocks on economic growth and inflation: Case study Iran. International Journal of Bussiness and Social Science, 3(9), 224-230.

Lucas, R. E. (1973). Some international evidence on output-inflation tradeoffs. American Economic Review, 63(3), 326-334. http://dx.doi.org/10.2307/1914364 
Lucas, R. E. (1986) Adaptive behavior and economic theory. Journal of Business, 59(4), 401-426. http://dx.doi.org/10.1086/296377

MacKinnon, J. G. (1996). Numerical distribution functions for unit root and cointegration tests. Journal of Applied Econometrics, $\quad$ 601-618. http://dx.doi.org/10.1002/(SICI)1099-1255(199611)11:6<601::AID-JAE417>3.0.CO;2-T

Marashdeh, O. (1993). Anticipated and unanticipated money: A case study of Malaysia. Applied Economics, 25(7), 919-925. http://dx.doi.org/10.1080/00036849300000071

McGee, R., \& Stasiak, R. (1985). Does anticipated monetary policy matter? Another look. Journal of Money, Credit, and Banking, 17, 16-27. http://dx.doi.org/10.2307/1992503

Mohabbat, K., \& Al-Saji, A. K. (1991). The effects on output of anticipated and unanticipated money growth: A case study of an oil-producing country. Applied Economics, 23(9), 1493-1497. http://dx.doi.org/10.1080/00036849100000201

Mishkin, F. S. (1982). Does anticipated monetary policy matter? An econometric investigation. Journal of Political Economy, 90(1), 22-51. http://dx.doi.org/10.3386/w0506

Muth, J. F. (1961). Rational expectations and the theory of price movements. Econometrica, 29(3), 315-335. http://dx.doi.org/10.2307\%2F1909635

Orphanides, A., \& Williams, J. C. (2005). Imperfect Knowledge, Inflation Expectations and Monetary Policy. In B. Bernanke \& M. Woodford (Eds.), The Inflation targeting debate (pp. 201-234). Chicago: University of Chicago Press.

Peker, O. (2007). Measurement of the monetary policy's effects: The case of Turkey. Journal of Management and Economics, 4(1), 181-194.

Sargent, T., \& Wallace, N. (1975). Rational expectations, the optimal monetary instrument, and the optimal money supply rule. Journal of Political Economy, 83(2), 241-254. http://dx.doi.org/10.1086\%2F260321

Sims, C. A. (1980). Macroeconomics and reality. Econometrica, 48(1), 1-48. http://dx.doi.org/10.2307/1912017

Sulku, S. N. (2011). Testing the long run neutrality of money in a developing country: Evidence from Turkey. Journal of Applied Economics and Business Research, 1(2), 65-74.

Taban, S. (2004). The conjunctural analysis of monetary policies within the framework of the neoclassical imperfect information model. Iktisat. Isletme and Finans Journal, 19(216), 123-131. http://dx.doi.org/10.3848/iif.2004.216.5108

Tanriover, B., \& Yamak, N. (2012). Asymmetric effects of monetary shocks: Theory and application for Turkey. Ege Academic Review, 12(3), 339-350.

Tuğcu, C. T. (2015). Testing the neutrality of money hypothesis: Cointegration analysis with structural break for the Turkish economy. Journal of Economic Policy Researches, 2(1), 17-31.

Uygur, E. (1983). Neoklasik makroiktisat ve fiyat bekleyişleri: Kuram ve Türkiye ekonomisine uygulama. Ankara: AÜ SBF Publishing.

Wogin, G. (1980). Unemployment and monetary policy under rational expectations: Some Canadian evidence. Journal of Monetary Economics, 6(1), 59-68. http://dx.doi.org/10.1016/0304-3932(80)90018-5

Yamak, R., \& Kucukkale, Y. (1998). Anticipated and unanticipated money in Turkey. Yapı Kredi Economic Review, 9(1), 15-25.

\section{Notes}

Note 1. Law No 4651 issued on 25.04.2001.

Note 2. The results of analyses using arithmetic mean support and are consistent with the results of this study.

Note 3. In estimates using capital goods as lower coefficients of determination than intermediate goods, more autocorrelation and heteroscedasticity problems were encountered and significance of all the independent variables were adversely affected. Intermediate goods are therefore preferred. 


\section{Appendix A}

CBRT explains The Modified Mean, Outlier, Extreme Outlier as follows.

"The Modified Mean: It is a statistic computed as a result of data analysis and elimination of observations judged to be atypical to develop an appropriate indicator of central tendency of a distribution. The modified mean is determined among statistics such as the arithmetic mean, the median, the mode, the mean computed by excluding outliers and extreme outliers as well as the trimmed mean by analyzing outliers and extreme outliers. If skewness and kurtosis values are close to those of a normal distribution, the arithmetic mean is regarded as the modified mean. If atypical values are identified in the distribution, the modified mean is computed by taking the arithmetic average after excluding outliers and extreme outliers. If skewness is relatively high, the median, if kurtosis is relatively high, meaning that the expectations are concentrated around a specific value, the mode is regarded as the modified mean" (CBRT, 2013, p. 2-3).

"Outlier: Values smaller than $Q 1-1.5 *(Q 3-Q 1)$ and greater than $Q 3+1.5 *(Q 3-Q 1)$; where Q1:Lower Quartile and Q3: Upper Quartile, computed by Tukey's Hinges method are defined as outliers" (CBRT, 2013, p. 3).

"Extreme Outlier: Values smaller than Q1-3*(Q3-Q1) and greater than Q3+3*(Q3-Q1); where Q1:Lower Quartile and Q3: Upper Quartile, computed by Tukey's Hinges method are defined as extreme outliers" (CBRT, 2013, p. 3).

\section{Copyrights}

Copyright for this article is retained by the author(s), with first publication rights granted to the journal.

This is an open-access article distributed under the terms and conditions of the Creative Commons Attribution license (http://creativecommons.org/licenses/by/3.0/). 